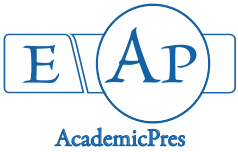

Jianu LD et al. (2021)

Notulae Scientia Biologicae 13(1):10875

DOI: $10.15835 / \mathrm{nsb} 13110875$

Research Article

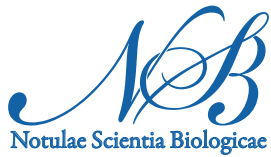

\title{
Silene thymifolia Sibth. et Sm. (Caryophyllaceae) - A vulnerable species in Romania: Anatomical aspects of vegetative organs
}

\author{
Loreley D. JIANU, Rodica BERCU, Dan R. POPOVICIU*
}

Ovidius University, Faculty of Natural and Agricultural Sciences, Aleea Universității, No. 1, 900470, Constanţa, Romania;

dr_popoviciu@yahoo.com ("corresponding author);prof.rodicabercu@gmail.com; jloreley@yahoo.com

\begin{abstract}
Silene thymifolia (Caryophyllaceae) is considered a rare, vulnerable species in Romania, growing only on Black Sea coastal dunes. Anatomical aspects of the root, stem and leaf of this species are presented in this study. Root, stem and leaves were analysed by brightfield microscopy, with specific staining. The root in cross section exhibited a secondary structure, generated by the activity of phellogen, and vascular cambium, with thick cork, continuous secondary xylem rings. no pith rays, but with cortical air lacunes. The stem had a primary structure with a number of collateral vascular bundles arranged on a single circle, with thick cortical schlerenchymal layers and oxalate crystals in pith cells. The epidermis showed stomata and glandular hairs. The leaf was amphystomatic leaf, with a heterogeneous mesophyll (equifacial type) and embedded vascular bundles, with a rounded mid rib surrounded by a parenchyma sheath. The spongy tissue has some large intercellular air spaces with druses. The mechanical tissue is well developed in the root and stem and poorly developed, represented by few collenchyma elements in the mesophyll, being represented by a continuous schlerenchyma fibers band present in root and stem and collenchyma in the leaf. The secretory histological elements were represented by epidermal glandular hairs and oxaliferous cells (druses) present in stem and leaf.
\end{abstract}

Keywords: anatomy; leaf; root; Silene thymifolia; stem

\section{Introduction}

Silene thymifoliaSibth. et $\mathrm{Sm}$. (syn. Silene pontica Brandzá) is one of the 700 species of Silene, the largest genus of the Caryophyllaceae family (Bernasconi et al., 2009). Silene thymifolia Sibth. et Sm. is a perennial plant with branched, woody stock. Stems are numerous, $15-20 \mathrm{~cm}$, procumbent or ascending to erect, scabridpuberulent (Figure 1). Leaves are small, fleshy, 8-20 mm long, ovate, rarely elliptic, conspicuously pubescent. The flowers are grouped in small numbers, in a dichasial inflorescence. Flower has a glandular-villous calyx, narrowly clavately, $12-15 \mathrm{~mm}$, and a corolla with white bifid petals, neck ligulae. Capsule $(8-9 \mathrm{~mm})$ is slightly longer than carpophore (7 mm; Săvulescu, 1953; Tutin, 1972).

Silene thymifolia is a vulnerable $(\mathrm{Vu})$ coastal dune plant species (Dihoru and Negrean, 2009) in Romanian Black Sea Coast. Concerning its sozological status, it is also considered as a rare (R) species (Dihoru and Dihoru, 1994) and near-threatened (NT) species (Oltean et al., 1994). On its ecology it is known that Silene thymifolia Sibth. et $\mathrm{Sm}$. is a hemicryptophyte $(\mathrm{H})$ characteristic on littoral dunes with spreading on

Received: 31 Dec 2020. Received in revised form: 02 Mar 2021. Accepted: 02 Mar 2021. Published online: 03 Mar 2021.

From Volume 13, Issue 1, 2021, Notulae Scientia Biologicae journal will use article numbers in place of the traditional method of continuous pagination through the volume. 
North-West Black Sea sandy seashores. According to Flora Europaea it is present on terrestrial maritime sands from Northern and Western coasts of Black Sea in Bulgaria, Romania, Russia (W) and Turkey (Tutin, 1972).

It is a heliophile species, spread in warm areas, with dry to moderately moist soils, neutral pH (Ciocârlan, 2009; Sârbu et al., 2013). Vegetal associations cited to contain Silene thymifolia are: Secali sylvestris-Alyssetum borzeani (Borza, 1931); Secali sylvestris-Brometum tectorum (Hargitai, 1940); Alysso borzaeani Ephedretum distachyae (Tzonev et al., 2005). These associations are part of two Natura 2000 natural habitat types: 2110 Embryonic shifting dunes, 2130 Fixed coastal dunes with herbaceous vegetation ('grey dunes'; Doniță et al., 2005; Gafta and Mountford, 2008).

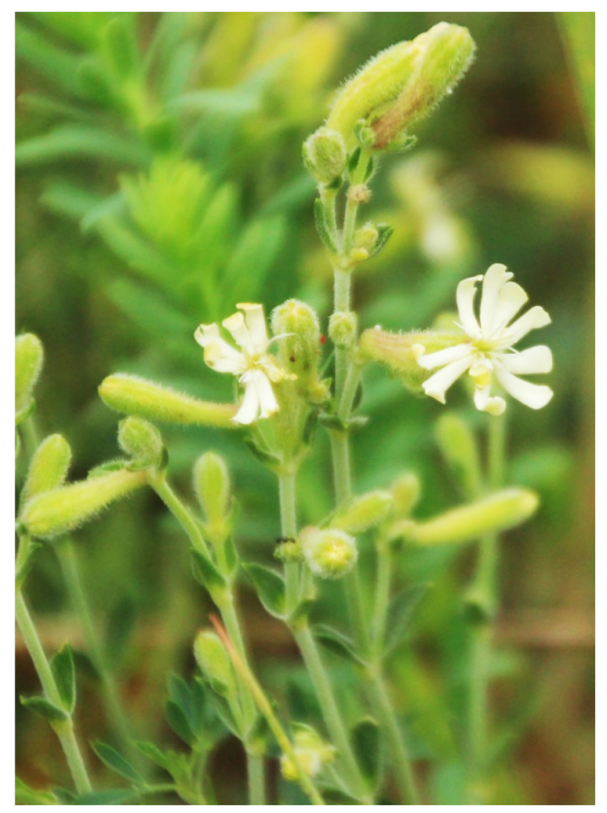

Figure 1. Silene thymifolia

(original photo Jianu L.D.)

Because of its habitat preference specificity (it grows only on marine sand dunes) the studied species is extremely rare so its current distribution in Romania includes only the Agigea Natural Reserve (Jianu and Făgăraș, 2015). The current conservation status of the Silene thymifolia regarding species distribution, population status and its future population perspectives have a totally inadequate and unfavourable conservation status. The habitat of local populations was heavily affected by the intensified human activities in the Romanian coastal area over the past 50-60 years (Jianu, 2014). Without the application of urgent protection and conservation measures the extinction of Silene thymifolia species from the Romanian flora is possible (Jianu, 2014) despite the effort to preserve small populations in the natural protected area Agigea Natural Reserve (according to its Management Plan).

Silenegenus is a very complex group of plants in terms of taxonomic because of its fairly uniform external appearance (Coode and Cullen, 1967). In literature, there are many studies regarding the morphological features, used mostly to establish the relationships among Silene species (Greuter, 1995; Y1ldız, 2002; Kilic and Ozcelik, 2008). Few data are known about the anatomy of Silene species vegetative organs. Succinct general information concerning anatomical characteristics of the Caryophyllaceae family (including Silene as well) belong to Metcalfe and Chalk (1950). Recent anatomical studies concerning a number of Silene species belong especially to Kilic (2009), Yildız and Minareci (2008), Fathi et al. (2010), Jafari et al. (2008), Keshavarzi et al. (2014), Bağci and Biçer (2015), but no detailed anatomical study for Silene thymifolia.

The purpose of this paper is to highlight anatomical features of Silene thymifolia and to contribute with more information to the knowledge concerning this taxon. 


\section{Materials and Methods}

\section{Biological material}

For anatomical analysis of the studied species, fresh plant material was collected from a small population found on Agigea Natural Reserve marine sand dunes (Constanța County, southeastern Romania). The biological material was represented by root, herbaceous stem and stem leaves, collected from plants at full maturity. Taking into account the status of endangerment of this plant, only fragments were collected from vegetative organs necessary for the respective anatomical sections.

\section{Anatomical analyses and micrographs}

Small pieces of root, stem and leaf were fixed in FAA (formalin: glacial acetic acid: alcohol 5:5:90). The cross sections were performed by freehand technique (Bercu and Jianu, 2003). The samples were stained with alum-carmine and iodine green and mounted with gelatine-glycerine to make permanent slides. Anatomical observations and micrographs were performed with a BIOROM-T bright-field microscope, equipped with a TOPICA 6001A video camera.

\section{Results and Discussion}

The cross section of the root, showed a thick cork (8-10 cell layers) generated by the cork cambium. Beneath the cork cambium there is the phelloderm, composed of a number of layers of living parenchyma cells. Some cells contain calcium oxalate crystals - druses. Rare air spaces are present (Figure 2A, B). The vascular cambium, composed of 2-3 layers of flattened cells, generates outwards the secondary phloem and inwards the secondary xylem. Phloem consists of phloem vessels, companion cells and phloem parenchyma. The secondary xylem (xylem vessels and xylem parenchyma) is more developed than phloem forming a continuous ring. The vessels are few in the center, more numerous towards the cambium, where the difference between spring and autumn wood tissue is clearly marked. The numerous xylem vessels are separated by small, compact, thin-walled cells. Medullary rays are absent. In the secondary xylem, toward the pith, a thick schlerenchyma ring (7-8 sclerenchymatous cells) is present (Figure 2A, C). The presence of intra-annual fiber bands in the xylem is the characteristic of Caryophyllaceae species growing at lower altitudes (Schweingruber, 2007).

Cross section of the stem has a circular-sinuous shape (Figure 3A). The outermost single-layered epidermis is represented by slightly tangentially elongated rectangular cells with thick internal and external walls and covered by a thick cuticle. The epidermis shows stomata and densely multicellular ( $4-5$ cells) glandular hairs (Figure 3B). Some of them are grouped in pairs.

The cortex, located just below the epidermis, consists of 4-5 cell layers, some of them with chloroplasts and others (fewer) with druses, followed by several layers of sclerenchyma cells, occupying a large area (9-10 layers) of the stem (Figure 3A, B). These findings, like those of Fathi et al. (2010) and Keshavarzi et al. (2014) in several other Silene species, place the thick, continuous ring of schlerenchymal fibers in the cortex. However, Bağci and Biçer (2015) suggest that it may belong to the stele. The presence of the sclerenchyma ring in the stem cortex and oxalate crystals in the pith parenchyma cells are common features in Silene species stem (Keshavarzi et al., 2014).

The vascular system is represented by a single ring of 9 open collateral vascular bundles. Phloem tissue consists of sieve cells, companion cells and phloem parenchyma. Xylem vessels are radially arranged, placed in a cellulosic parenchyma (Figure 3C). The vascular bundles are separated by rays of cells with cellulosic walls. The cambium zone is not easily distinguishable, a situation similar to that reported by Ylldiz and Minareci (2008) for Silene urvillei stem. 


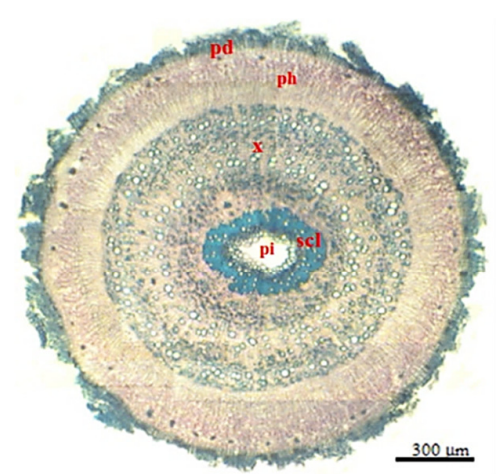

(A)

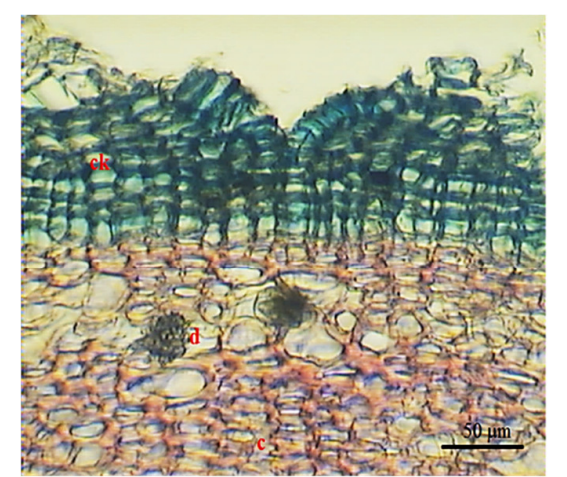

(B)

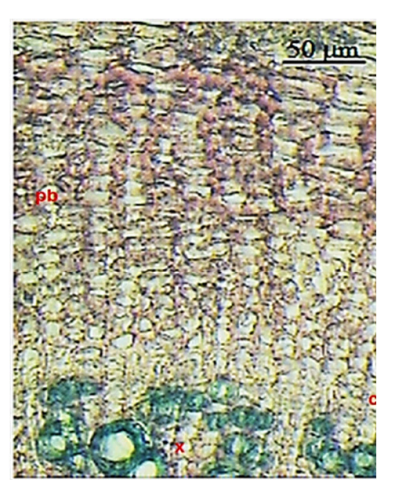

(C)

Figure 2. Cross section of the root; (A) Ensemble; (B) Portion with cork and cortex; (C) Portion of the stele

cb- cambium, ck- cork, d- druse, pd- periderm, ph- phloem, pi- pith, scl- sclerenchyma, $x$ - xylem

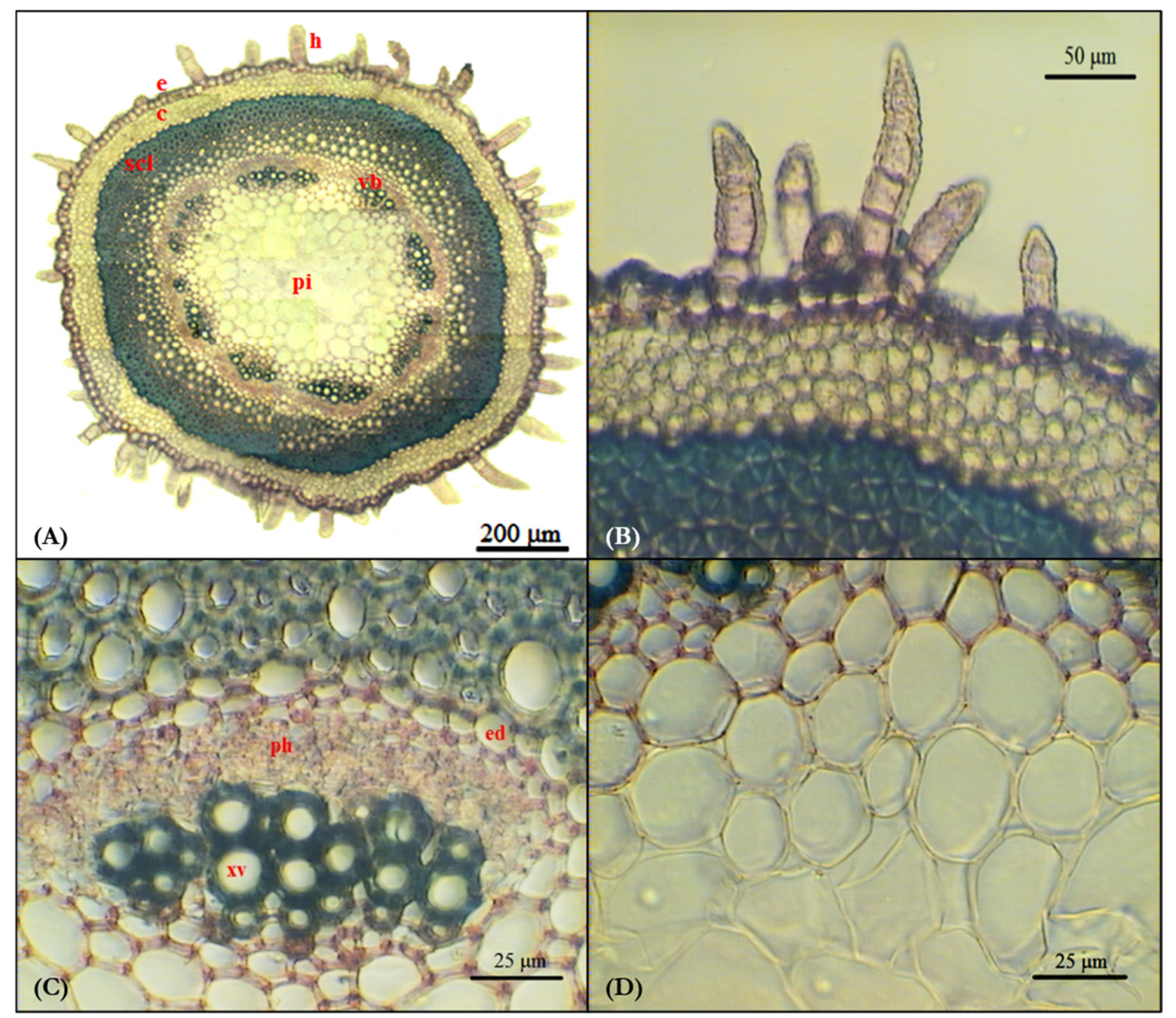

Figure 3. Cross section of the stem; (A) Ensemble; (B) Portion with cortex; (C) A vascular bundle of the stele; (D) Pith

c- cortex, e- epidermis, ed- endodermis, h- hair, pi- pith, ph- phloem, scl- schlerenchyma, vb- vascular bundle, $x v-x y l e m$ vessel 
The centrally located pith is composed of parenchyma cells, some of them possessing calcium oxalate crystals. Some empty spaces occur due to pith cells disorganization, this area being gradually replaced by a pith lacuna (gap) in mature stages (Figure 3D).

The cross section of the leaf blade exhibited an upper and lower single-layered epidermis with tangential slightly elongated cells and covered by a thick cuticle. Both epidermises show stomata with substomatal cavities of various sizes (amphistomatic leaf) and hairs. The same type of glandular hairs on the stem are present, especially on the lower epidermis, more abundant close to the mid rib zone (Figure 4A). Hairs placed close to the mesophyll margins are longer than the others. The upper epidermis cells are larger than those of the lower one. The lower and upper epidermis are slightly prominent in the mid rib zone.

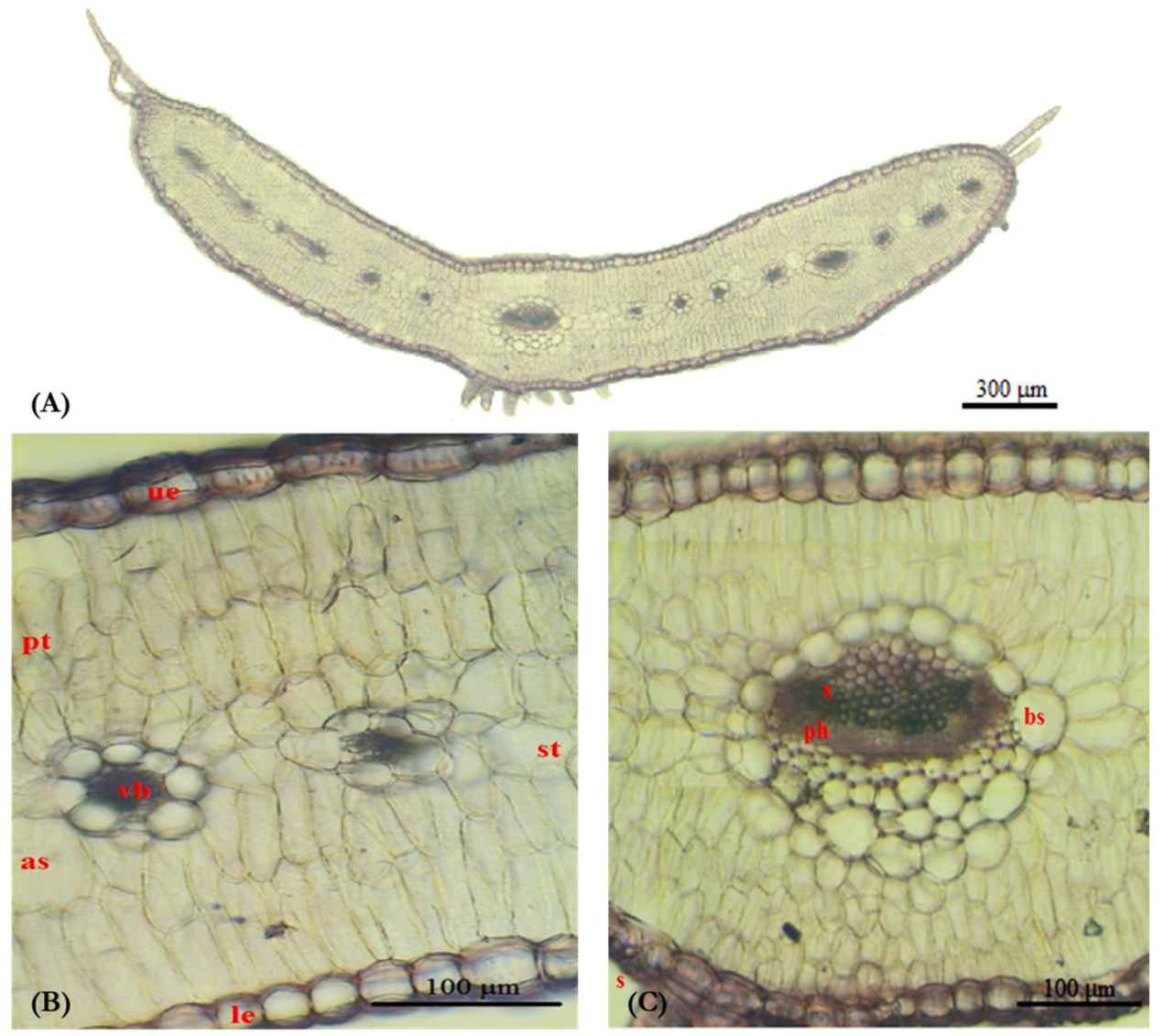

Figure 4. Cross section of the leaf; (A) Ensemble; (B) Portion with mesophyll and secondary veins; (C) Portion of the mid rib zone

as- air space, bs- bundle sheath, le- lower epidermis, ph- phloem, pt- palisade tissue, sp- spongy tissue, ue- upper epidermis, vb- vascular bundle, $x$ - xylem

The mesophyll has both palisade and spongy tissue. The palisade tissue is placed bellow the upper and lower epidermis (equifacial type; Figure 4B, C). The mesophyll had druses in its large lacunes. The roundshaped mid rib is represented by a collateral vascular bundle surrounded by a parenchymatous bundle sheath (Figure $4 \mathrm{C}$ ). The secondary vein bundles possess few conductive elements and a single-layered bundle sheath around them (Figure 4B). 


\section{Conclusions}

The root has a secondary structure due to the activity of the phellogen and vascular cambium, without pith rays and with some air spaces in the cortex. The stem has a primary structure with a number of collateral vascular bundles arranged on a single circle. The leaf is amphystomatic with an equifacial mesophyll and a rounded mid rib surrounded by a parenchyma sheath. The spongy tissue has some large intercellular air spaces with druses.

The secretory histological elements are represented by epidermal glandular hairs and oxaliferous cells (druses) present in stem and leaf. The mechanical tissues are represented by a continuous schlerenchyma fibres band present in root and stem and collenchyma in the leaf.

\section{Authors' Contributions}

Conceptualization: LDJ and RB; Data curation: RB and DRP; Formal analysis: RB; Investigation: LDJ and RB; Methodology: LDJ and RB; Software: DRP; Supervision: RB; Validation: LDJ and RB; Visualization: DRP; Writing - original draft: RB; Writing - review and editing: DRP. All authors read and approved the final manuscript.

\section{Acknowledgements}

This research received no specific grant from any funding agency in the public, commercial, or not-forprofit sectors.

\section{Conflict of Interests}

The authors declare that there are no conflicts of interest related to this article.

\section{References}

Bağci Y, Biçer H (2015). Analysis of anatomical and morphological characters of the Silene cappadocica Boiss. \& Heldr. and Silene spergulifolia Bieb. (Caryophyllaceae) species. Scientific Papers, Series B, Horticulture 59:293-302.

Bercu R, Jianu LD (2003). Practicum de morfologia și anatomia plantelor [Plant morphology and anatomy practicum]. "Ovidius" University Press, Constanța.

Bernasconi G, Antonovics J, Biere A, Charlesworth D, Delph LF, Filatov D, ... Widmer A (2009). Silene as a model system in ecology and evolution. Heredity 103:5-14. https://doi.org/10.1038/hdy.2009.34

Ciocârlan V (2009). Flora ilustrată a României [Illustrated flora of Romania]. Ceres, Bucharest.

Coode MJE, Cullen J (1967). Silene L. In: Davis PH [Ed]. Flora of Turkey and the East Aegean Islands. Vol. 2, University Press, Edinburgh pp 179-242.

Dihoru G, Dihoru A (1994). Plante rare, periclitate şi endemice în Flora României. Lista Roșie. [Rare, endangered and endemic plants in Romanian flora. The Red List]. Acta Botanica Horti Bucurestiensis 1994:173-197.

Dihoru G, Negrean G (2009). Cartea roşie a plantelor vasculare din România [Red book of vascular plants in Romania]. Editura Academiei Române, Bucharest.

Doniță N, Popescu A, Paucă-Comănescu M, Mihăilescu S, Biriş AI (2005). Habitatele din România [Habitats of Romania]. Editura Tehnică Silvică, Bucharest.

Fathi Z, Jafari A, Zokai M (2010). Comparative study of stem structure and wood analysis in different species of Silene L. genus (Mashhad and countryside). Journal of Plant Environmental Physiology 5:28-35. 
Gafta D, Mountford JO (2008). Manual de interpretare a habitatelor Natura 2000 din România [Handbook for interpreting Natura 2000 habitats in Romania]. Risoprint, Cluj-Napoca.

Greuter W (1995). Silene (Caryophyllaceae) in Greece: A subgeneric and sectional classification. Taxon 44:543-581. https://doi.org/10.2307/1223499

Jafari A, Zokai M, Fathi Z (2008). A biosystematical investigation on SileneL. species in North-East of Iran. Asian Journal of Plant Sciences 7:394-398. https://doi.org/10.3923/ajps.2008.394.398

Jianu LD (2014). Determination of the conservation status and measures required for the protection of some plant species with high vulnerability of the Romanian Black Sea littoral. PhD Thesis, Romanian Academy, Institute of Biology, Bucharest.

Jianu LD, Făgăraș M (2015). Several issues regarding the conservation and protection of vulnerable prammophylous species Polygonum maritimum L. and Silene thymifolia Sibth. et Sm. at the Romanian Black Sea coast. Annals of the University of Craiova - Agriculture, Montanology, Cadastre Series 15:164-172.

Keshavarzi M, Mahdavinejad M, Sheidai M, Gholipour A (2014). Anatomical study of some Silene L. species of Lasiostemones Boiss. section in Iran. Acta Biologica Szegediensis 58:15-19.

Kilic S (2009). Anatomical and pollen characters in the genus Silene L. (Caryophyllaceae) from Turkey. Botany Research Journal 2:34-44. https://doi.org/10.5505/biodicon.2019.07379

Kilic S, Ozcelik H (2008). Taxonomic revision of Silene L. sect. Brachypodae (Boiss.) Chowdhuri (Caryophyllaceae). International Journal of Natural and Engineering Sciences 2:59-63.

Metcalfe CR, Chalk L (1950). Anatomy of the Dicotyledons. Vol. 2. Clarendon Press, Oxford.

Oltean M, Negrean G, Popescu A, Roman N, Dihoru G, Sanda V, Mihăilescu S (1994). Lista roşie a plantelor superioare din România. Studii, sinteze, documentații de ecologie [The red list of vascular plants in Romania. Studies, syntheses, ecological documentations]. Vol. 1. Editura Academiei Române, Bucharest.

Săvulescu T (Ed) (1953). Flora României [Flora of Romania]. Vol. 2. Editura Academiei RPR, Bucharest.

Sârbu I, Nicolae S, Oprea A (2013). Vascular plants in Romania. Illustrated field determinator. Victor B. Victor, Bucharest.

Schweingruber FH (2007). Stem anatomy of Caryophyllaceae. Flora 202:281-292. https://doi.org/10.1016/j.flora.2006.07.004

Tutin TG, Heywood VH, Burgess A, Moore DM, Valentine DH, Walters SM, Webb DA (1972). Flora Europaea. Vol. 3. Cambridge University Press, Cambridge.

Yildiz K (2002). Seed morphology of Caryophyllaceae species from Turkey (Northern Anatolia). Pakistan Journal of Botany 34:161-171.

Ylldı K, Minareci E (2008). Morphological, anatomical, palynological and cytological investigation on Silene urvillei Schott. (Caryophyllaceae). Journal of Applied Biological Sciences 2:41-46.
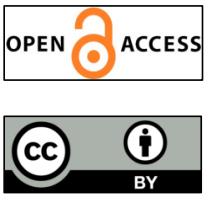

The journal offers free, immediate, and unrestricted access to peer-reviewed research and scholarly work. Users are allowed to read, download, copy, distribute, print, search, or link to the full texts of the articles, or use them for any other lawful purpose, without asking prior permission from the publisher or the author.

License - Articles published in Notulae Scientia Biologicae are Open-Access, distributed under the terms and conditions of the Creative Commons Attribution (CC BY 4.0) License.

(c) Articles by the authors; SHST, Cluj-Napoca, Romania. The journal allows the author(s) to hold the copyright/to retain publishing rights without restriction. 